\title{
Characterization of Organic Matter Preserved in the Triassic Lockatong Formation in the Newark Basin
}

\author{
Diana Beatriz Tinoco ${ }^{1}$ and Larbi Rddad ${ }^{2}$ \\ 1. Kingsborough Community College, 2001 Oriental Boulevard, Brooklyn, NY 11235, USA \\ 2. Kingsborough Community College, Earth and Planetary Sciences, Department of Physical Sciences, 2001 Oriental Boulevard, \\ Brooklyn, NY 11235, USA
}

Received: February 15, 2015 / Accepted: March 05, 2015 / Published: March, 202015.

\begin{abstract}
This study is aimed at characterizing the organic matter preserved in the Triassic Lockatong formation deposited in the Newark Basin. On the basis of the TOC (Total Organic Carbon), the Lockatong formation was deposited in a reducing environment in the deep NW part of the basin, which is favorable to the accumulation of organic matter. However, the Lockatong formation of the SE border of the basin was deposited in oxic conditions that prevented the preservation of organic matter if there is any. The structuration of the basin into deep subsiding NW section due to the reactivation of the NE-SW striking faults and the development of anoxic conditions were favorable for the accumulation and preservation of the organic matter in the deep part of the basin.
\end{abstract}

Key words: Newark basin, organic matter, Lockatong formation.

\section{Introduction}

The Newark basin, located in New Jersey, is a half-graben formed during the Triassic rifting. In this basin, alluvio-lacustrine facies were deposited (Fig. 1). This basin has been investigated by many authors and for different purposes, such as sedimentology, tectonic, and organic geochemistry. In fact, the Triassic Lockatong formation, deposited in the subsiding basin, was previously studied for its hydrocarbon potential [1]. However, the organic matter preserved in the Triassic Lockatong, deposited in the SE border of the basin, has not been previously investigated. This paper, thus, aims at characterizing the organic matter preserved in this formation, outcropping in the border of the basin and also provides an insight into the conditions/factors under which organic matter was preserved. To that end, Total Organic Carbon was analyzed in the Lockatong formation in the SE border

Corresponding author: Larbi Rddad, professor, research fields: ore geology and organic geochemistry. E-mail: Lrddad@gmail.com. of the basin and, then, compared to that of the deep section.

\section{Geological Context}

Newark basin was formed during the Triassic time when Pangaea started to break apart 200 million years ago. The structuration of the basin into a half-graben was caused by the reactivation of the NE-SW normal faults (Figs. 1 and 2). This basin began to be filled with Triassic alluvial and lacustrine sediments that were intercalated with three basaltic flows (Hook Mountain, Preakness, and Orange Mountain basalts) and igneous intrusions [2, 3]. The NW section of the basin was deep, due to subsidence, and thus received a thick sedimentary pile. However, the SE border of the basin section was shallower and accumulated a thin sedimentary pile.

This structuration of the basin into deep subsiding areas was ideal for the accumulation and preservation of organic matter. The rocks, outcropping in the studied area, belong to the SE border part of the basin. 


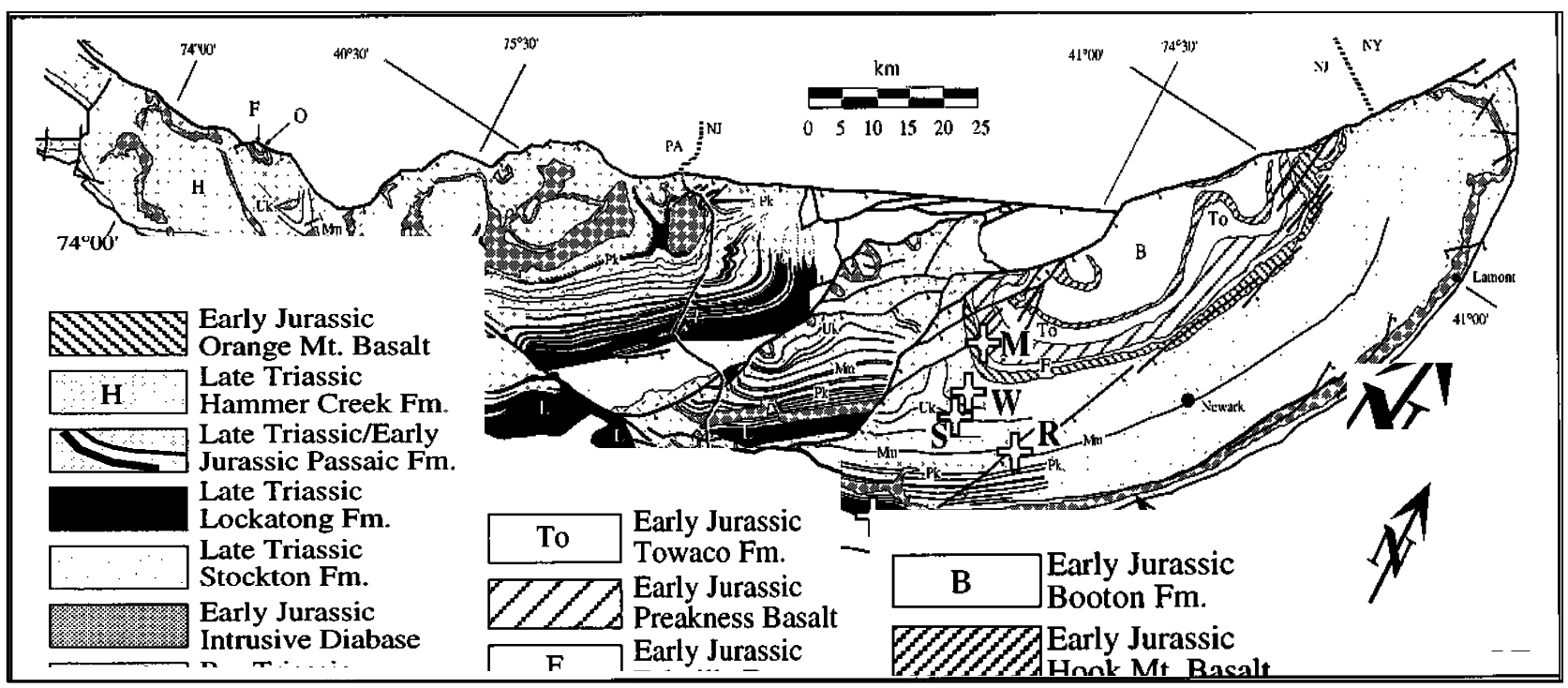

Fig. 1 Geological map of the Newark Basin $[3,4]$.

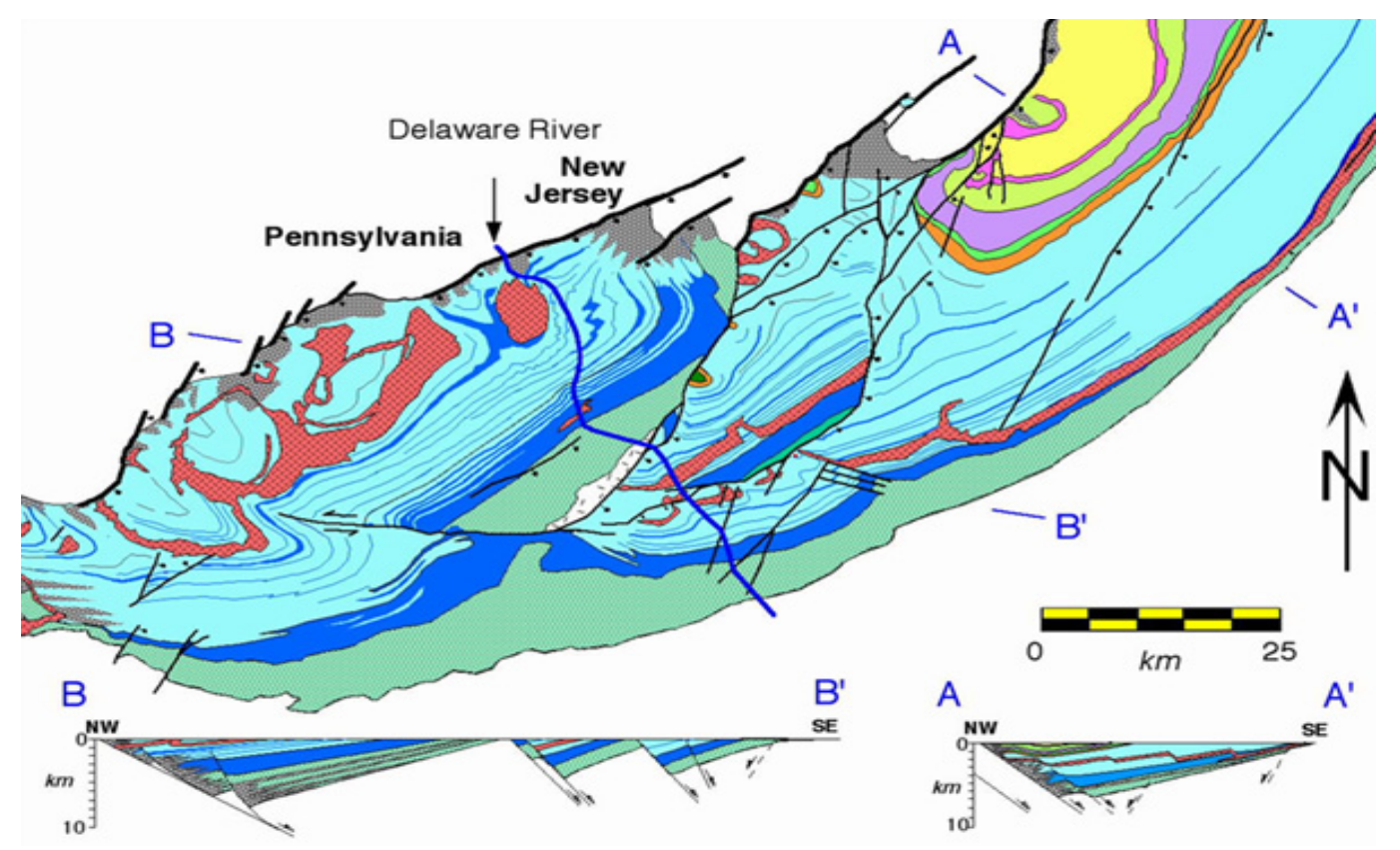

Fig. 2 Geological map and cross sections in the Newark Basin [5].

These rocks consist of alternating light and dark gray laminated siltstone and mudstone (Fig. 3).

\section{Materials and Methodology}

Seven samples were collected in the studied area, located in the SE border of Newark basin. These samples were powdered and weighed $(200 \mathrm{mg})$. The powdered samples were placed in porcelain "boat" and digested with acid to eliminate carbonates. The acid digestion was performed at $60{ }^{\circ} \mathrm{C}$ over one night.
The organic carbon of the samples was obtained by the combustion of dry residual sample at $1,100{ }^{\circ} \mathrm{C}$ by a Carmograph. The concentrations of the Total Organic Carbon were determined by comparison to a standard. The analysis of TOC was performed at the United States Geological Survey in New York.

\section{Results and Discussion}

The TOC values are reported in Table 1 and graphed in Fig. 3. The TOC values range from 13.86 


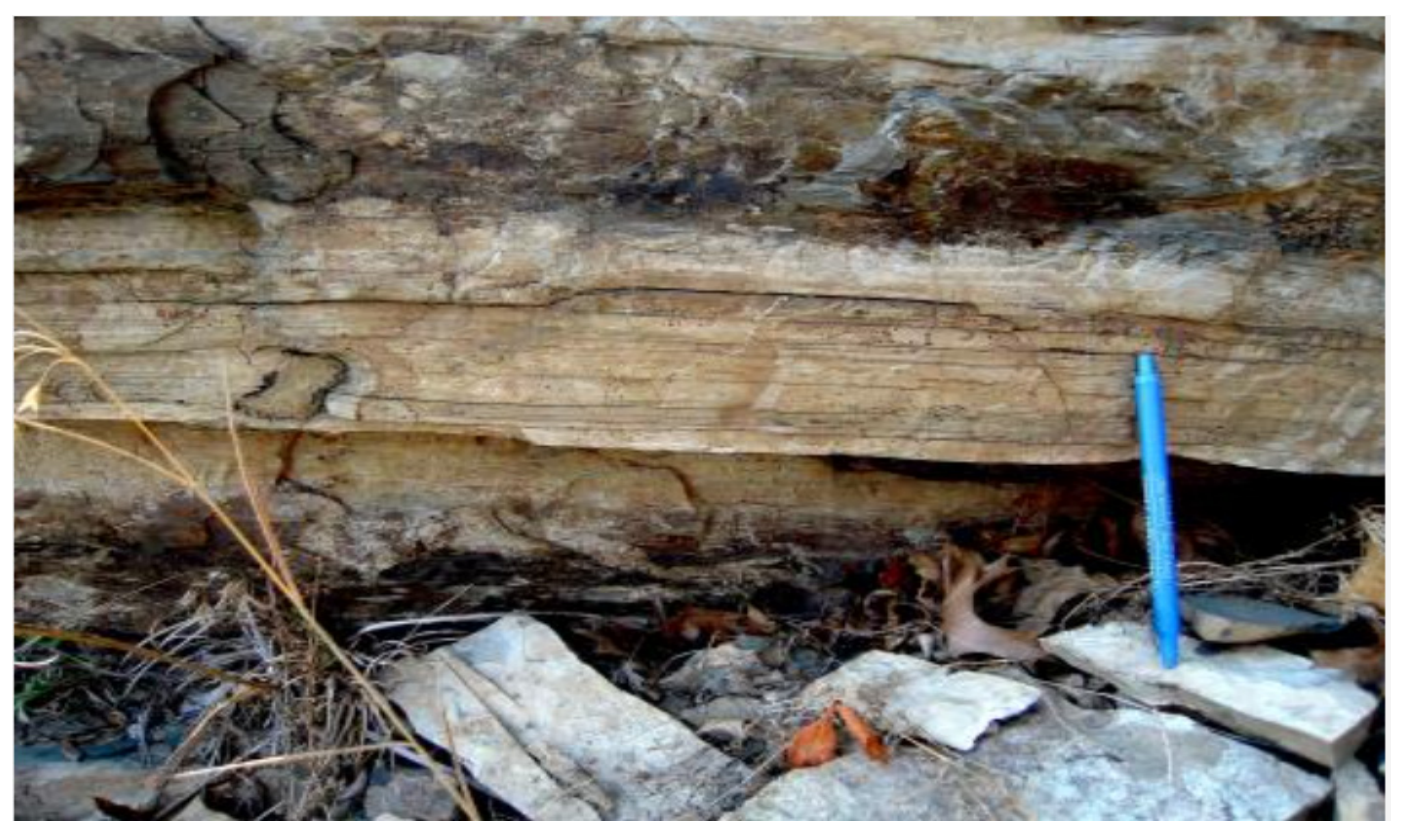

Fig. 3 Alternating dark and light siltstone/mudstone layers.

Table 1 Total Organic carbon expressed in ppm and percent in the Lockatong formation

\begin{tabular}{lllll}
\hline Sample & Rock description & Mass $(\mathrm{mg})$ & TOC $(\mathrm{ppm})$ & TOC $(\%)$ \\
\hline Standard & & 20.2 & & 1.4924 \\
S3 & Dark gray mudstone to siltstone & 46.37 & 153.78 & 0.015378 \\
S4 & Gray mudstone to siltstone & 45.9 & 111.26 & 0.011126 \\
S5 & Dark gray mudstone to siltstone & 47.61 & 32.02 & 0.003202 \\
S10 & Light gray mudstone to siltstone & 53.48 & 89.79 & 0.008979 \\
S11 & Light gray mudstone to siltstone & 56.62 & 131.4 & 0.01314 \\
S12 & Dark gray mudstone to siltstone & 67.97 & 51.25 & 0.005125 \\
S13 & Dark gray mudstone to siltstone & 59.46 & 13.86 & 0.001386 \\
\hline
\end{tabular}

ppm to 153.78 ppm. Often dark colored laminated rocks register higher TOC values than light colored ones. However, the TOC values, registered in the studied samples, vary from $13.86 \mathrm{ppm}$ to $153.78 \mathrm{ppm}$ for dark colored rocks and from $89.79 \mathrm{ppm}$ to 131.4 ppm for light colored ones (Fig. 3). This observation indicates the absence of correlation between the color of the rock and its TOC content. The dark color of these rocks is not due to the organic matter content, but probably to the mineral composition.

Regardless of the color of the rock, the TOC values are extremely low. According to Ref. [6], rocks with TOC values less than $0.50 \mathrm{wt} \%$ are considered poor source rocks (Table 2). Therefore, the rocks of the studied area are very poor source rocks. Characterization of the type and the quality of organic matter, using Rock-Eval, is not further investigated because of these extremely low TOC values.

Compared to the studied area, belonging to the SE border of the basin, the Lockatong formation deposited in the deep NW part of the basin is rich in organic matter with TOC values ranging from $0.2 \%$ to $6.0 \%$ [1]. This observation suggests differences in the accumulation and/or preservation of the organic matter in the deep and border parts of basin. The deep subsiding basin was favorable to the accumulation and preservation of organic matter due to the anoxic conditions that prevailed during the deposition of the Lockatong formation [7]. This conclusion is supported by the occurrence of uranium, which is associated with high TOC values [8]. The uranium is, in fact, fixed to organic matter in a reducing, anoxic 


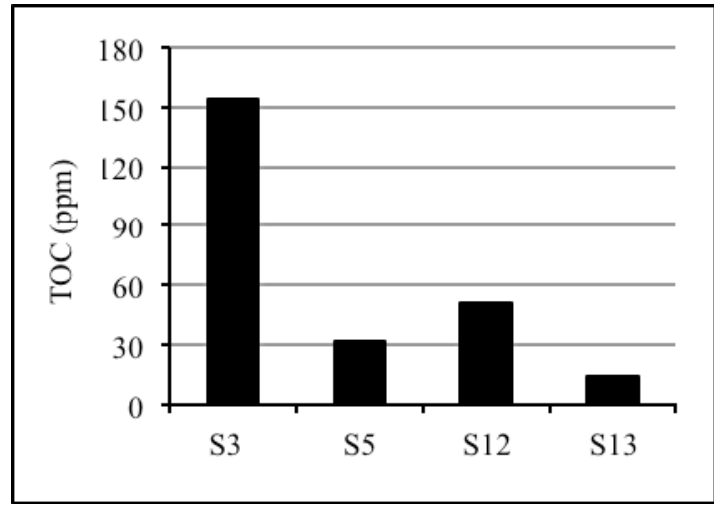

(a)

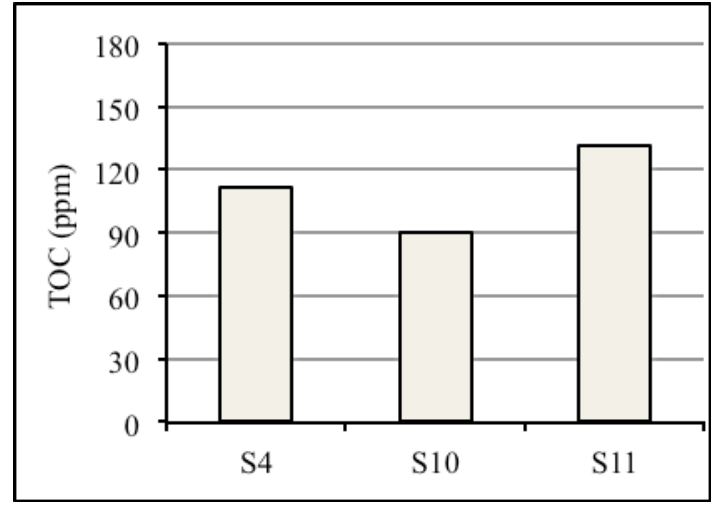

(b)

Fig. 4 TOC values in dark (a) and light colored rocks (b) in the SE border of the Newark basin.

Table 2 TOC values that indicate quality of different source rocks [6].

\begin{tabular}{ll}
\hline Quality & TOC wt \% \\
\hline Poor & $0-0.50$ \\
Fair & $0.50-1$ \\
Good & $1-2$ \\
Very good & $>2$ \\
\hline
\end{tabular}

environment [8]. Moreover, the occurrence of bitumen in the Lockatong formation in the deep section of the basin indicates that this formation is not only rich in organic matter but reached maturity. However, in the SE border, the very low TOC values reflect the lack of biomass productivity and/or the oxic conditions that prevented the preservation of organic matter, if there is any. In fact, the border of basin was too shallow to allow for the development of anoxic conditions necessary to preserve the organic matter.

Subsidence of the basin and the prevalence of anoxic conditions are determinant factors in the accumulation of organic matter in the deep section of the basin [7]. More work is needed in different parts of the basin to thoroughly characterize the hydrocarbon potential of the basin.

\section{Conclusion}

Newark basin was structured into a half-graben during Triassic time. The deep NW part of the basin was favorable to the accumulation and preservation of organic matter. However, the lack of biomass productivity and/or oxic conditions prevented the accumulation and preservation of organic matter in the SE shallow border of the basin. The structuration of the basin into deep anoxic environment was due to the reactivation of NE-SW striking faults. The development of a subsiding basin and the prevailing anoxic conditions are crucial in the preservation and accumulation of organic matter in this formation. Further geochemical studies, throughout the basin, are needed to make a generalization.

\section{Acknowledgments}

We would like to thank the New York State Geological Survey, Albany for the TOC analysis. We also thank the NE Urban Metropolitan Travel Grant Program and Kenneth N. Weaver Student Travel Award Program for funding the travel expenses that allowed the first author to attend the GSA professional meeting.

\section{References}

[1] Olsen, P. E. 1984. "Comparative Paleolimnology of the Newark Supergroup-A Study of Ecosystem Evolution.” Ph.D. dissertation, Yale University.

[2] Schlische, R. W. 1992. "Structural and Stratigraphic Development of the Newark Extensional Basin, Eastern North America: Evidence for the Growth of the Basin and Its Bounding Structures." Geological Society of America 104: 1246-63.

[3] Schlische, R. W., and Olsen, P. E. 1990. "Quantitative Filling Models for Continental Extensional Basins with Applications to the Early Mesozoic Rifts of Eastern North America." Journal of Geology 98: 135-55. 
[4] Olsen, P. E., Kent, D. V, Cornet, B., Witte, W. K, and Schlische, R. W. 1996. "High-Resolution Stratigraphy of the Newark Rift Basin (Early Mesozoic, Eastern North America)." GSA Bulletin 108 (1): 40-77.

[5] Schlische, R. W. 2003. Progress in Understanding the Structural Geology, Basin Evolution, and Tectonic History of the Eastern North American Rift System. New York: Columbia University Press.

[6] Peters, K. E. 1986. "Guidelines for Evaluating Petroleum Source Rock Using Programmed Pyrolysis." AAPG
Bulletin 70 (3): 318-29.

[7] Tinoco, D., and Rddad, L. 2015. "A Preliminary Study Comparing the Organic Matter Preserved in the Lockatong Formation in the Deep and Border Parts of Newark Basin." In Proceedings of Geological Society of America (GSA) Northeastern Section-50th Annual Meeting, 51.

[8] Turner-Peterson, C. E, Olsen, P. E., and Nuccio, V. F. 1985. "Modes of Uranium Occurrence in the Newark Basin, New Jersey and Pennsylvania." U.S. Geological Survey Circular 946: 120-2. 